Portland State University

PDXScholar

School of Music + Theater Faculty Publications and Presentations

$5-2017$

\title{
Entrepreneurship And Pr Skills For Music Students
}

Tomás Cotik

Portland State University, tcotik@pdx.edu

Follow this and additional works at: https://pdxscholar.library.pdx.edu/music_fac

Part of the Music Education Commons, Musicology Commons, and the Music Practice Commons Let us know how access to this document benefits you.

Citation Details

Cotik, Tomás, "Entrepreneurship And Pr Skills For Music Students" (2017). School of Music + Theater Faculty Publications and Presentations. 5.

https://pdxscholar.library.pdx.edu/music_fac/5

This Article is brought to you for free and open access. It has been accepted for inclusion in School of Music + Theater Faculty Publications and Presentations by an authorized administrator of PDXScholar. Please contact us if we can make this document more accessible: pdxscholar@pdx.edu. 


\section{ENTREPRENEURSHIP AND PR SKILLS FOR MUSIC STUDENTS}

by Tomas Cotik

In a successful ensemble, not only do musicians need to spend countless hours mastering their instruments and improving their ensemble playing, they also need to be entrepreneurial, media savvy, and their own managers and promoters-in other words, able to deal with a variety of non-musical endeavors.

\section{A Good Way to Get Started}

One way for students to learn some of the skills they will need to survive and strive as musicians in the twenty-first century is by organizing projects while they are still in college. Challenging our students to create artistic projects can motivate them to progress and accomplish their goals and musical dreams.

A good way to get started is by encouraging them to manage all aspects of their own ensemble concerts and to bring music to audiences from various backgrounds in their community. Forming their own ensembles, organizing off-campus recitals, creating an interdisciplinary collaboration, and organizing all the aspects surrounding a performance will be enriching on a social and personal level-as well as helpful in reflecting across disciplines and gaining critical and independent thinking skills. By doing such projects, students will be accountable for themselves, enhance their communication, acquire analytical and problem-solving skills-all while getting familiar with the tools and platforms they will continue to use as professionals.

The drive in these projects should be each student's own artistic vision. It allows students to create their own opportunities, and they should be encouraged to question conventional practices. A relatively small project can jumpstart their curiosity and encourage them to take advantage of current online resources to produce music, make recordings and videos, develop a press kit, create their own webpage, book performances, fundraise, engage with their communities, and create relations with the media.

\section{A Guide to Concert Planning}

Thankfully, there are many apps and programs they can learn to use quickly and independently. What follows is a simple outline for your students-a starting guide to some useful resources and aspects to consider when organizing an offcampus performance, keeping in mind that the most important part will be to learn by doing:

- Brainstorm as a group all the aspects and possibilities you can think of for your project. Think of your own artistic vision as well as your career goals, and try to find some common ground. Discuss ideas with your group that could make your event and program unique, special, different, and original in order to be both attractive for the audience and interesting for you. Think of possible collaborations. For example, you could invite dancers to join, an actor to introduce, or a scholar to give a pre-concert lecture. Besides the exchange with other colleagues, your project will be appealing to a wider audience. When considering the repertoire, don't always start with the best-sellers. Research the literature. Use Naxos Music Library to discover and explore new music.

- Plan a strategy. It is a good idea to make a to-do list and to divide the chores among the members of the group. To start, identify which unique non-musical skills and interests each member has. You could use graphic design, web design, networking, photography, public speaking, writing, and organizing logistics, just to name a few.

- If you need to find one or more spaces to perform, start by contacting possible venues. You can research where other music groups are playing in and around town, or check the directory of presenters on Musical America and Chamber Music America. An even better idea is to start with venues where you might already have some kind of connection. A non-traditional venue could be a good idea as well. For example, a religious institution, a library, coffee shop, retirement home, orphanage, farmers market, grocery store, airport, etc.

- Decide on a ticket price. The concert could also be free admission or a fundraiser. If you need funds to produce the concert and the project, you could consider creating a fundraising campaign with Kickstarter or creating your own nonprofit with Fractured Atlas.

- Create a name for the ensemble and write a short bio. Be sure to have updated pictures, edited individual bios, and some notes about the pieces and the composers. Create a press kit and use Dropbox to share your media files.

- Start planning PR as early as possible after you have formed your chamber music group and have decided on a program. Prepare a timetable. Use Basecamp to communicate with your team, manage your milestones, and share files.

- Make a poster for the concert. An app like Phoster allows you to create this quickly and easily. Distribute your poster around town, at your school, or to local businesses.

- Compile a media list for your town. Musical America has a comprehensive list. Create a press release and send it to the media. Contact the radio and student newspaper and tell them your story. Enter the performance information on calendar listings for your town. Invite music critics if you are confident that the project could have a happy ending.

- $\quad$ Share your event information, poster, etc. on social media and on your webpage. If you don't have one, write that on your Evernote to do list. WordPress is great platform to build your website, and GoDaddy can be used to buy a domain and to host your page. 


\section{Challenging our students to create artistic projects can motivate them to progress and accomplish their goals and musical dreams.}

- Create an event on Facebook and use Instagram, Twitter, etc. to keep your family, friends, and fans posted and interested in your event. You can share short video recordings as sneak previews of the show. Record your rehearsal live on Facebook or Periscope. Upload recordings to YouTube and SoundCloud.

- Create a list of your contacts and send them one or two email blasts with MailChimp. Include the poster and information about your concert. If you don't have a big mailing list, increase it with NoiseTrade. Use ReverbNation to connect with your fans and Eventbrite to promote and sell tickets.

- Design and print programs for the concert.

- Plan a couple of run-throughs of the program before your main concert for family and friends. Also plan a dress rehearsal time at the venue.

- Decide who would be able to do a video/audio recording of the concert and make all the necessary arrangements. Find friends to sell tickets, distribute programs, and sell CDs or merchandise with Square. Organize and plan a concert reception.

- Decide on concert attire-hopefully something exciting! Speak with each other about stage presence. A good idea is to start using tablets/iPads for the scores if you are not doing so already. AirTurn has good pedals and forScore works great with your iPad. Rehearse getting on stage and coordinate the greeting to the audience as well as bows. Decide who will speak to the audience, write the notes, and rehearse it.

- Go over the technical requirements for the concert. Make sure there are chairs, stands, and stand lights, if necessary. If different groups will perform during the concert, plan on having a designated stagehand for setup between groups, and give that person a diagram of how you will sit in advance of the performance. Make a schedule for the date of the concert for yourself as well as for the stagehand.

- It doesn't hurt to send a last reminder to people you want to attend, as this will increase attendance.

- $\quad$ After the concert, post the video on social media. Sell a recording on Bandcamp after doing some editing with Audacity. Finally, thank all the people who helped you get to this point-helpers, teachers, guests, media, and critics!
None of this is rocket science, but it does take a lot of work, time, and energy! You won't have time to complete everything if you start shortly before your first important professional project. That's why it is important to get going as soon as you have a good playing level and feel ready to start sharing your musical voice. It will be an ongoing process; when you start to become more successful, you can (and should) outsource some of these tasks-so you can practice more!

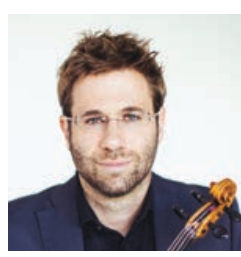

Tomas Cotik has performed hundreds of recitals and chamber music concerts across the globe. He currently is a member the Cotik/Lin duo, and has been a member of the acclaimed Amernet, Delray, and Harrington string quartets. Cotik earned a Doctor of Musical Arts degree from the University of Miami. He holds Bachelor and Master of Music degrees from the Freiburg University of Music in Germany. Committed to passing on his passion for music, Cotik is assistant professor of violin at Portland State University. He previously taught at West Texas A\&M University, Florida International University, and the University of Miami's Frost School of Music. 